\title{
Sex-workers in a Country of Largest Muslim Population
}

\author{
Myrtati D. Artaria ${ }^{1} \&$ Sri E. Kinasih ${ }^{1}$ \\ ${ }^{1}$ Universitas Airlangga, Indonesia \\ Correspondence: Myrtati D. Artaria, Universitas Airlangga, Indonesia. E-mail: myrtati.artaria@fisip.unair.ac.id
}

Received: January 6, 2017

Accepted: February 7, $2017 \quad$ Online Published: May 31, 2017

doi:10.5539/ass.v13n6p31

URL: https://doi.org/10.5539/ass.v13n6p31

\begin{abstract}
Indonesia is the largest Islam country in the world that has the biggest number of Muslims among other countries in the world. Hence this is the reason of the local governments, the governor of East Java Province and the mayor of Surabaya, to close the red-light areas. The purpose of this research is to know how the women became sex-workers in the biggest number of Muslims in the world. We observed and interviewed 20 informants of sex workers and former sex-workers; the Head of Local Health Center, NGO in those areas, and midwives. The data that had been collected were classified into themes. While being analyzed, the report was written and being classified. The results show that although the nation vows that every individual in this country has a religion, and mostly are Muslims, but prostitution is difficult to inhibit. We found many reasons that have made the women fell into the world of prostitution in this area of East Java. After the closing of the red-areas we found that they have secretly continue doing their job because they do not have other skills that can make as much as money that they earned as sex-workers. We conclude that the purpose to preserve a good religious environment by closing the red-areas cannot be realized. The closing of the red-areas has brought new problems because the spread of HIV/AID and sexually transmitted disease are more difficult to control.
\end{abstract}

Keywords: red-area, prostitution, sex-worker

\section{Introduction}

Indonesia is the largest Islam country in the world that has the biggest number of Muslims among other countries in the world. Hence this is the reason of the local governments, the governor of East Java Province and the mayor of Surabaya, to close the red-light areas. One reason for this closure is because it is not in accordance with the conditions of a religious community, for the localization of red-areas means allowing religious offenses occurred, and validated them in a structured way.

The problem is, throughout the world, prostitution is difficult to eradicate. Prostitution may have existed since the first presence of human being. It is precisely that the function of the existence of localization was to oversee sexually transmitted diseases and HIV/AIDS to be suppressed or prevented, by requiring regular health inspections, requirement of condoms to prevent the contamination of HIV/AIDS, and treatment of infectious diseases as soon as they were detected.

With the closing of red-areas localization, the preventive measures above cannot be done anymore, because prostitution done covertly without the knowledge of the government. Protection from the pimp, although at the same time controlling the life of the sex-workers; in many cases also protected them from the careless conduct of the users.

Apart from the above mentioned, the question is whether the closing down of the red-areas that is being said to be the contrary to the religious life of the surrounding community, is reasonable. Most of the people living nearby are Muslims. After the closing of the areas, will prostitution persist or continue? Then, as a country that has the biggest number of Muslims in the world, which current direction is assumed to become increasingly more religious, with a growing number of women wearing the hijabs (Smith-Hefner, 2007), and men against leaders of other faiths (Hasan, 2002); how these women finally became sex-workers from the first part? What are the reasons they chose to become sex-workers? The state of Indonesia requires each of its citizens to have a religion, but then why it cannot prevent them from activities that violate their religion doctrines, even further being commercial sex-workers? 


\section{Methods}

In order to obtain empirical data and information, the researcher conducted a descriptive research applying qualitative approach. First of all, the locations of this research were determined purposively. This research was conducted in six red-light areas: Dupak Bangunsari, Tambak Asri, Moroseneng, Kalakah Rejo, and Dolly. These areas were "hotspots" of red-light areas in Surabaya which had been operated for a long period of time. These red-light areas were the targets of Governor Decree Number 260/15612/031/2011 and 460/15612/031/2011 which was to be closed on the year of 2014.

The data collection was based on observation and in-depth interview. There were 20 informants consisting of sex workers and former sex-workers; the Head of Local Health Center, NGO in those areas, and midwives.

We interviewed the sex-workers regarding how they ended up earning money their way, how they were trafficked - if they were, and how the economy of their trade works. The Head of Local Health Center and the midwives gave us information of how the sex-workers accessed the health facilities in the area, they also gave us information of how the sex-workers in these areas are prone to sexual transmitted diseases, and how they never showed up at the health facilities again after the closing of the red areas. Thus, giving problems to the health practitioners to continue treating the girls from sexually transmitted diseases. We also interviewed NGO working around these areas, and they gave us information on the complex problems in stopping the sex-workers from doing their business in these areas. They gave us information how the government's programs supposed to operate, and how applicable the program is in the red-areas society.

Later, the data that had been collected were classified into themes. While being analyzed, the report is written and the data are being classified to make the reader better understand them.

\section{Results and Discussion}

\subsection{Backgrounds and Driving Factors of Becoming Sex-workers}

Based on observed cases and results of interviews and focus group discussions, there are ten factors which of becoming a prostitute. They are:

\subsubsection{Economic Factor}

One of driving factors why a woman decided to become a prostitute was her family economic background. They came from poor families such as farmers, construction workers, small traders, and prostitutes. Economic motive was the main reason why our informants were willing to become a prostitute. They wanted to escape from poverty and relieved their family financial burden. Being a prostitute was considered as a survival strategy because by being a prostitute they could gain extra income for their family.

Economic factor has been a well-known reason for many women to overcome their needs, When they do not have any other skills that can overcome the financial problems (Manopaiboon, 2003; Reed et al., 2010).

\subsubsection{Educational Background}

Our informants came from families with low-education backgrounds. Most of our informants were low-educated. Most of them were elementary school graduated, even some of them did not finish their elementary schools. This condition made them easily tricked and recruited to become a prostitute. Poverty and low-motivation of the prostitutes themselves and their families were the main factors why they did not continue their study. Many other countries experience the same issues (Mayer, 2013; Morris et al., 2013, Saggurti et al., 2013).

\subsubsection{Coming from Poor and Geographically Isolated Regions}

Our informants--like most of trafficking victims-- were originated from poor and geographically isolated regions. This condition made them vulnerable to sexual broker and pimp tricks who promised them to get a better living. This too has been mentioned by Tyner (2013).

\subsubsection{Broken Home Family}

Most of our informants came from broken home family. Their parents divorced and one of (or both of) their parents were unknown. This condition caused our informants did not have any discussion partners or lacking of consideration when a person attempt to recruit them to become a prostitute. They tended to fall into trick and becoming a prostitute. This was the case in other areas too which reported by Demartoto (2013).

\subsubsection{Coming from Sexual Worker Family}

Many of our informants came from sexual worker family. Their mothers were prostitutes. This made them did not think twice to follow their mothers to become a prostitute, such case was Rtn, one of our informants. Being a 
prostitute is considered as normal in the family because the profession could financially support their family. Experiences during childhood and offensive life in daily environment are influencing factors to prostitution (Schaffer \& De Blassie, 1984).

\subsubsection{Lack of Understanding and Awareness about Trafficking}

Our society had not fully understood and been aware that some cases which they often met were part of trafficking practices. They did not consider these cases as trafficking which violated human rights. Therefore, they rarely reported these cases to police. Eventually, many of our society became ignorant to these cases.

\subsubsection{Women and Children Vulnerability in Socio-cultural Life}

Almost all of trafficking victims were women and children. It may be caused by their position as "second-grade citizen" in some societies. This position made them easily tricked and some people thought that women and children were deserved to be a prostitute, beggar, or housemaid. Not all men think that women are equal to men (Kartini, 1976; Rimonte, 1991; Niaz, 2003; Man, 2004; Othman, 2006).

\subsubsection{Lack of Information and Weak Communication}

Almost all of our informants were lacking information and experiencing weak communication skill. This condition made them easily trust information from unknown people who offered and promised a better living abroad or in other cities--as in Rtn's case. They tended to believe the promise and directly took the offer without seeking for further information.

\subsubsection{Early Marriage}

Early marriage was commonly found in rural areas where girls who were graduated from junior high schools or even elementary schools got married based on her parents arrangement. However, because their age was not legal to get married they tend to falsify their ages to obtain ID card and get married. Early marriage tends not to long-lasting which forces them to divorce--as in Mrt and Sr's cases. When separated from the husband, and not having a good skill for work, they tend to fall into the trap of prostitution.

\subsubsection{Being Tricked}

All of our informants admitted they had been tricked to become a prostitute. They believed the person who promised them to get a good job, and took the opportunity. The job promised did not relate to any sexual activities, but when they are brought to the strange land, the fact was surprising. Mrt, one of our informants admitted she had been forced to become a prostitute by a person who promised her a job. Having no one to protect her, she could not escape from the new reality. This happens in other places too (McMullen, 1987; Bromberg, 1997; Bamgbose, 2002). When this happened, either they were so protected by the pimp so that they could not run away, or they were too ashamed to go back home, and felt unworthy. Many of the societies in Indonesia highly value virginity, and girls who lost their virginity think that they have no future to find a descent husband.

\subsection{What Happened after the Closing of the Red-areas?}

Closing the red-area district was meant to maintain a good religious society. However, can this purpose be preserved? The closing of four red-light areas in Surabaya: Sememi (Moroseneng), Klakah Rejo, Tambak Asri (Kremil), and Dupak Bangunsari had been planned by Surabaya government since early 1990s (https://www.merdeka.com/peristiwa/ini-alasan-risma-tutup-lokalisasi). This means Surabaya government owns a legal basis - the Local Government Regulation Number 7/1999, to prevent utilization of any building in Surabaya as prostitution location. According to Surabaya Social Agency (Dinas Sosial Kota Surabaya), the closing of four red-light districts had been accepted and decided by religious leaders and public figures in these areas. As it has been stated by Bernardin (1984) that religious leader may have important roles in decision making in the public policy.

The closing of Sememi, Klakah Rejo, Tambak Asri, and Dupak Bangunsari were very easy. The closing were coincided with religious recitation attended by Surabaya Mayor, Tri Rismaharini. Religious recitation is an activity that is often held by the society every week, in most Islamic religion communities in Indonesia. The support of religious people can be used to reinforce the plan of the government to complete the action of closing the red-light areas. Using religion to legitimate an action by a government has been done before, even for a long time; such as related to health issues, as stated by Campbell et al. (2007).

There was no specific sanction for the sex workers or specific preparation made by Surabaya government. After the closing, those who conducted prostitution practice would be warned and subjected to criminal law. Using law as enforcement of banning red-light areas has been done in several places such as Ireland, Iceland, and Malta 
(Hibbeln, 1998), and Sweden (Ekberg, 2004).

The closing of Dolly and Jarak were very difficult compared to other four red-light areas (Dupak Bangunsari, Klakah Rejo, Sememi, and Tambak Asri). In these four areas, the sex workers were poor. Hence, they needed and were satisfied with the compensation money provided by the government. In the contrary, the sex workers in Jarak and Dolly were richer and had a strong network. They did not need compensation money provided by the Surabaya Government. This situation often caused conflicts between Surabaya government and the sex workers. Explicitly, the sex workers declared their rejection on government plan to close the prostitution area. However these actions failed and the closing of the areas were finally realized.

According to our informants and our observation, in order to find income as much as they had before, several sex-workers tried to survive by obtaining their old consumers, but they stay in regular boarding houses mingled with other workers around and outside the old red-areas. Some others tried to maintain good relationship with the old pimps and operate illegally in more spread out places.

Although we found the causes of the girls to choose to stay in this business, but we must say that there might be information that we might miss, because the nature of this job is unusual, so that there might be unknown causes that we have missed. We acknowledge that the connection between the sex-workers, the pimps, and the customers are very complex.

\section{Conclusion}

We can conclude that the purpose to preserve a good religious environment by closing the red-areas cannot be realized. The closing of the red-areas has brought new problems because the spread of HIV/AID and sexually transmitted disease are more difficult to control. The government has difficulties to monitor the location of the new area of prostitution because the sex-workers are practicing secretly.

\section{Acknowledgements}

I would like to thank DIKTI for funding this research, under PUPT scheme. I would like to thank Dr. Pinky S. E. Pratiwi and Drs. Pudjio Santoso, M.Sosio as partners in doing the bigger theme of research. This article is part of a bigger research, titled "Building integrated clinic as an effort to overcome HIV/AIDS after the closing of red-areas in Surabaya“" ([Membangun Klinik Terpadu sebagai Upaya Penanggulangan HIV/AIDS Pasca Penutupan Lokalisasi di Surabaya]).

\section{References}

Bamgbose, O. (2002). Teenage prostitution and the future of the female adolescent in Nigeria. International Journal of offender therapy and comparative criminology, 46(5), 569-585. http://journals.sagepub.com/doi/abs/10.1177/030662402236741

Bernardin, J. C. (1984). Role of the religious leader in the development of public policy. Journal of Law and Religion, 2(2), 369-379. https://doi.org/10.2307/1051097

Bromberg, S. (1997). Feminist issues in prostitution. In International conference on prostitution. Retrieved August (Vol. 10, p. 2008). https://scholar.google.co.id/scholar?hl=en\&q=\%5BBromberg\%2C+S.+\%281997\% 29. + Feminist + issues + in + prostitution. + In + International + conference + on + prostitution $\% 5 \mathrm{D} \& b \operatorname{btn}=$

Campbell, M. K., Hudson, M. A., Resnicow, K., Blakeney, N., Paxton, A., \& Baskin, M. (2007). Church-based health promotion interventions: evidence and lessons learned. Annu. Rev. Public Health, 28, 213-234. http://annualreviews.org/doi/abs/10.1146/annurev.publhealth.28.021406.144016

Demartoto, A. (2013). The existence and the effect of sex tourism habitus in Bandungan, Central Java, Indonesia. Asian Social Science, 9(15), 93. https://doi.org/10.5539/ass.v9n15p93

Ekberg G. (2004). The Swedish Law that prohibits the purchase of sexual services best practices for prevention of prostitution and trafficking in human beings. Violence Against Women, 10(10), 1187-1218. http://journals.sagepub.com/doi/abs/10.1177/1077801204268647

Hasan, N. (2002). Faith and politics: The rise of the Laskar Jihad in the era of transition in Indonesia. Indonesia, (73), 145-169. http://cip.cornell.edu/seap.indo/1106940156

Hibbeln, J. R. (1998). Fish consumption and major depression. Lancet, 351(9110), 1213. https://www.infona.pl/resource/bwmeta1.element.elsevier-a6f4cc47-331f-34c9-9603-e4bf90e00e45

https://www.merdeka.com/peristiwa/ini-alasan-risma-tutup-lokalisasi-gang-dolly-mati-matian.htm l. Accessed 26 September 2016. Newspaper online. 
Kartini, R. A. (1976). Letters of a Javanese princess. Kuala Lumpur: Oxford University Press.

Man, G. (2004). Gender, work and migration: Deskilling Chinese immigrant women in Canada. In Women's Studies International Forum, 27(2), 135-148. Pergamon. http://www.sciencedirect.com/science/article/pii/S0277539504000172

Manopaiboon, C., Bunnell, R. E., Kilmarx, P. H., Chaikummao, S., Limpakarnjanarat, K., Supawitkul, S., ... \& Mastro, T. D. (2003). Leaving sex work: Barriers, facilitating factors and consequences for female sex $\begin{array}{llllll}\text { workers in } & \text { northern }\end{array}$ http://www.tandfonline.com/doi/abs/10.1080/012021000039743

Mayer, K. H., Wheeler, D. P., Bekker, L. G., Grinsztejn, B., Remien, R. H., Sandfort, T. G., \& Beyrer, C. (2013). Overcoming biological, behavioral and structural vulnerabilities: New directions in research to decrease HIV transmission in men who have sex with men. Journal of acquired immune deficiency syndromes (1999), 63(0 2), S161. 10.1097/QAI.0b013e318298700e https://www.ncbi.nlm.nih.gov/pmc/articles/PMC3740716/

McMullen, R. J. (1987). Youth prostitution: A balance of power. Journal of Adolescence, 10(1), 35-43. https://doi.org/10.1016/S0140-1971(87)80031-3

Morris, M. D., Lemus, H., Wagner, K. D., Martinez, G., Lozada, R., Gómez, R. M. G., \& Strathdee, S. A. (2013). Factors associated with pathways toward concurrent sex work and injection drug use among female sex workers who inject drugs in northern Mexico. Addiction, 108(1), 161-170. http://onlinelibrary.wiley.com/doi/10.1111/j.1360-0443.2012.04016.x/full

Niaz, U. (2003). Violence against women in South Asian countries. Archives of women's mental health, 6(3), 173-184. https://ink.springer.com/article/10.1007\%2Fs00737-003-0171-9?LI=true

Othman, N. (2006). Muslim women and the challenge of Islamic fundamentalism/extremism: An overview of Southeast Asian Muslim women's struggle for human rights and gender equality. Women's Studies International Forum, 29(4), 339-353). Pergamon. http://dx.doi.org/10.1016/j.wsif.2006.05.008

Reed, E., Gupta, J., Biradavolu, M., Devireddy, V., \& Blankenship, K. M. (2010). The context of economic insecurity and its relation to violence and risk factors for HIV among female sex workers in Andhra Pradesh, India. Public Health Reports, 81-89. http://journals.sagepub.com/doi/abs/10.1177/00333549101250S412

Rimonte, N. (1991). A question of culture: Cultural approval of violence against women in the Pacific-Asian community and the cultural defense. Stanford Law Review, 1311-1326. http://www.jstor.org/stable/1229041

Saggurti, N., Sabarwal, S., Verma, R. K., Halli, S. S., \& Jain, A. K. (2013). Harsh realities: Reasons for womens involvement in sex work in India. Journal of AIDS and HIV Research, 3(9), 172-179. http://www.academicjournals.org/journal/JAHR/article-full-text-pdf/D88AC4E2930

Schaffer, R., \& De Blassie R. R. (1984). Adolescent prostitution. Adolescence, 75, 689-696. http://search. proquest.com/openview/a34081a47bf11 faa6719f10555728105/1?pq-origsite=gscholar\&cbl=1819054

Smith-Hefner, N. J. (2007). Javanese women and the veil in post-Soeharto Indonesia. The Journal of Asian Studies, 66(2), 389-420. https://doi.org/10.1017/S0021911807000575

Tyner, J. A. (2013). Population geography I: Surplus populations. Progress in Human Geography, 37(5), 701-711. Retrieved from http://journals.sagepub.com/doi/abs/10.1177/0309132512473924

\section{Copyrights}

Copyright for this article is retained by the author(s), with first publication rights granted to the journal.

This is an open-access article distributed under the terms and conditions of the Creative Commons Attribution license (http://creativecommons.org/licenses/by/4.0/). 